\title{
How Motivation Influences Student Engagement: A Qualitative Case Study
}

\author{
Sitwat Saeed ${ }^{1} \&$ David Zyngier ${ }^{1}$ \\ ${ }^{1}$ Faculty of Education Monash University, Melbourne Australia \\ Correspondence: David Zyngier, Faculty of Education, Monash University, PO Box 527 Frankston 3199 , \\ Australia. Tel: 61-399-044-320. E-mail: david.zyngier@monash.edu
}

Received: August 6, 2012

Accepted: October 24, 2012

Online Published: November 27, 2012

doi:10.5539/jel.v1n2p252

URL: http://dx.doi.org/10.5539/jel.v1n2p252

\begin{abstract}
The authors use Ryan and Deci's (2000) Self-Determination Theory (SDT) to better understand how student motivation and engagement are linked combined with Schlechty's Student Engagement Continuum to analyse the impact of intrinsic and extrinsic motivation on students' different engagement types. The study seeks to understand which type of motivation - intrinsic or extrinsic - is more closely aligned to authentic student engagement as identified by Schlechty $(2002,2011)$. A qualitative research framework was adopted and data was collected from one elementary school class. According to Ryan and Deci's SDT, the majority of students who indicated that their motivation type was either intrinsic or integrated regulated motivation also demonstrated that they were authentically engaged in their education (Schlechty, 2002, 2011). The students who preferred extrinsic motivation also showed ritual and retreatist forms of engagement and students demonstrating both intrinsic and extrinsic motivation showed authentic, ritual, retreatist and rebellious engagement. In line with findings by Zyngier (2008) in this particular study at least, when pedagogical reciprocity (Zyngier, 2011) was present, intrinsic motivation assisted authentic student engagement in learning, and that extrinsic motivation served to develop ritual engagement in students however, students who had both types of motivation showed different types of engagement in their learning.
\end{abstract}

Keywords: student motivation, student engagement

\section{Introduction}

\subsection{Motivation and Engagement}

Together with motivation, engagement is viewed in the literature as very important for enhanced learning outcomes of all students (Schlechty, 2001; Woolfolk \& Margetts, 2007). Motivation is seen as a pre-requisite of and a necessary element for student engagement in learning. Student engagement in learning is not only an end in itself but it is also a means to the end of students achieving sound academic outcomes (Russell, Ainley \& Frydenberg, 2005; Ryan \& Deci, 2009). This is important because authentic engagement may lead to higher academic achievement throughout student life (Zyngier, 2008). If educators want to know and resolve the young students' issues and to make schools engaging places (Meyer, 2010; Smyth and McInerney, 2007), then they actually have to listen to what students are saying about their classes and teachers (Mitra, \& Serriere, 2012; O'Brien, \& Lai, 2011; Potter \& Briggs, 2003; Zyngier, 2011).

\subsection{Why is Connecting Student Motivation to Student Engagement Important}

Student engagement recognizes the complexity of engagement beyond the domains of cognition, behaviour, emotion or affect, and in doing so encompasses the historically situated individual within their contextual variables (such as personal and familial circumstances) that at every moment influences how engaged an individual (or group) is in their learning. This paper's significance is that it proposes to analyze which type of motivation - intrinsic or extrinsic - is more aligned to and related with authentic student engagement as defined by Schlechty $(2001,2011)$ where the "...task, activity, or work the student is assigned or encouraged to undertake is associated with a result or outcome that has clear meaning and relatively immediate value to the student" (Schlechty, 2011, n.p). Newmann (1992) states that engaged students make a:

...psychological investment in learning. They try hard to learn what school offers. Students take pride not simply in earning the formal indicators of success (grades for example), but in understanding the 
material and incorporating or internalizing it in their lives" (p. 1).

Newmann's definition, like Schlechty's, implies that students who are engaged are involved in their own learning. For a truly engaged learner, the joy of learning inspires a persistence to accomplish the desired goals even in the face of difficulty (Schlechty, 2001). Engaged students have the skills to work with others and know how to transfer knowledge to solve problems creatively. The most engaging work allows for creativity, sparked curiosity, provided an opportunity to work with others, and produced a feeling of success. On the other hand, work that is repetitive, requires no thought, or is forced on students (Bowen, 2003) leads to strategic or ritual compliance, retreatism or worse, rebellion (Schlechty, 2011).

Students are engaged when they are involved in their work, persist despite challenges and obstacles, and take visible delight in accomplishing their work (Schlechty, 2001). Student engagement also refers to a "student's willingness, need, desire and compulsion to participate in, and be successful in, the learning process promoting higher level thinking for enduring understanding" (Bomia, Beluzo, Demeester, Elander, Johnson, \& Sheldon, 1997, p. 294).

This study was designed to understand students' perceptions about their own motivation type and how this may influence and impact on student engagement. Students respond differently to intrinsic and extrinsic motivation and each motivation type results in different form of engagement in and with their learning (Bowen, 2003; Newmann, 1992, 2001; Schlechty, 2001, 2011). Using student voice the researchers analyze the students' perceptions about their own motivation type and how these might impact theformation of authentic student engagement. This research not only seeks to identify the relationship between student motivation and engagement, but also explores the different types of engagement from authentic to rebellion (Schlechty, 2001, 2011) that may result from and be related to different types of motivation, from self determined intrinsic through to extrinsic and a-motivation (Ryan \& Deci, 2009).

\subsection{Research Question}

The researcherssought to determine the impact of student's perceptions of their preferred motivation typeonthe students' engagement levels.Russell et al. (2005) hold that for higher learning outcomes students are required to engage authentically (Schlechty, 2001, 2011) in their learning. There is much interest and concern in Australia and elsewhere (Newmann, 1996) with regard to student motivation, engagement and academic achievement in the middle years of schooling. According to Murray, Mitchell, Gale, Edwards and Zyngier (2004) the middle years of schooling for the past 20 years has become a significant research area in Australia. The National Middle Schooling Project found that a significant number of middle school students are not deriving benefits from schooling (Barratt, 1998). Main and Bryer, (2007) contend that in "Australian schools, middle schooling has become a popular educational reform that aims to meet the academic and socio-emotional developmental needs of young adolescents" (p. 91).

\subsection{Relevant Scholarship}

\subsubsection{Motivation}

According to Ryan and Deci (2000),

To be motivated means to be moved to do something. A person who feels no impetus or inspiration to act is thus characterized as unmotivated, whereas someone who is energized or activated toward an end is considered motivated. (p. 54)

In the classroom setting, student motivation refers to the degree to which a student puts effort into and focus on learning in order to achieve successful outcomes. Motivation and engagement are very important for sound student learning. Sternberg (2005) believes that motivation is very important for school success, in its absence; the student never may make an effort to learn.

Students not only have different quantities, but also different qualities of motivation that can vary from time to time depending on the learning and teaching context (Ryan \& Deci, 2000; Schlechty, 2001). If teachers have a sound understanding of the different types of student motivation possible in any given context, then they are in better position to provide a more conducive learning environment to students that better promotes their learning (Marsh, 2000). Kohn (1999, p. 257) contends that "the implicit premise of the words "intrinsic" and "extrinsic" is that there are qualitatively different kinds of motivation, and the kind matters more than the amount."

Corpus, McClintic-Gilbert and Hayenga (2009) expand this typology further:

The question of what motivates children's behavior in achievement contexts is one of long-standing interest to psychologists and educators. Much of the research in this area has classified motivation as 
either intrinsic (i.e., inherent to the self or the task) or extrinsic (i.e., originating from outside of the self or the task). That is, students are often thought to be learning either for the sake of learning or as a means to some other end, whether it be praise, tangible rewards, or meeting the demands of powerful authority figures. (p. 154)

Numerous research studies have shown that intrinsically motivated students have higher achievement levels, lower levels of anxiety and higher perceptions of competence and engagement in learning than students who are not intrinsically motivated (Wigfield \& Eccles, 2002; Wigfield \& Waguer, 2005). These studies demonstrate that there is a positive correlation between intrinsic motivation and academic achievement (Corpus et al., 2009; Law, Elliot, \& Murayama, 2012; Lee, McInerney, Liem, \& Ortiga, 2010; Lepper, Corpus \& Iyenger, 2005).

However, every student is not and cannot be always intrinsically motivated towards certain tasks. According to Krause, Bochner and Duchesne (2006) teachers frequently use extrinsic motivation like rewards, praise, free time, food and even punishment to encourage and stimulate their students towards learning. The majority of researchers believe that motivation is not exclusively intrinsic or extrinsic in orientation.A balanced pedagogical approach in the classroom includes the combination of both types (Harackiewicz \& Sansone, 2000; Harackiewicz \& Hidi, 2000; Hidi, 2000; Lepper \& Henderlong, 2000; Williams, \& Williams, 2011). The efficacy of intrinsic and extrinsic motivations depends on time and context. Educators may use these at a particular time and or in a certain activity. Similarly, the same activity can be seen as intrinsically or extrinsically motivating by different students (Areepattamannil, Freeman, \& Klinger, 2011; Butler, 2012; Guay, Chanal, Ratelle, Marsh, Larose, \& Boivin, 2010; Pintrich \& Schunk, 2002).

It is very important for educators to understand the different types of extrinsic motivation and how they may work as they cannot always rely on intrinsic motivation to promote learning. Many of the class room activities that a teacher wants students to do are not necessarily in themselves interesting or enjoyable therefore, using more active and volitional forms of extrinsic motivation such as electronic media sources are effective strategies for successful teaching (Ryan \& Deci, 2000).

Ryan and Deci (2000) proposed a Self Determination Theory (SDT) in order to:

Make the critical distinction between behaviors that are volitional and accompanied by the experience of freedom and autonomy-those that emanate from one's sense of self-and those that are accompanied by the experience of pressure and control and are not representative of one's self. (p. 65)

Intrinsic and extrinsic motivation is premised on the basic needs of autonomy, relatedness and competency, and how these support intrinsic motivation.

Ryan and Deci's SDT proposes that some types of extrinsic motivations are weak, whereas, some are active and agentic states. They describe different forms ofextrinsic motivation as a continuum starting from a-motivation (not motivated); to externalregulation (where a task is attempted to satisfy an external demand); introjected regulation (a task is done for ego enhancement); identification (where the task is valued for itself) andintegrated regulation which is the most autonomous kind of extrinsic motivation and exists whenexternal regulations are fully assimilated in a person's self evaluations and beliefs of their ownpersonal needs. Integrated motivations therefore share qualities with intrinsic motivation,but are still classified as an extrinsic from of motivation. The goals that the learner is trying to achieve are hencefor reasonsextrinsic to the inherent enjoyment or interest in the task. Intrinsic motivation is at the end of this continuum. Understanding the different types of extrinsic motivation is veryimportant as the types of extrinsic motivations show how much a student is self determinedduring a learning task and also shows the quality of effort he or she is putting into a task (Reeve, Deci \& Ryan, 2004). 


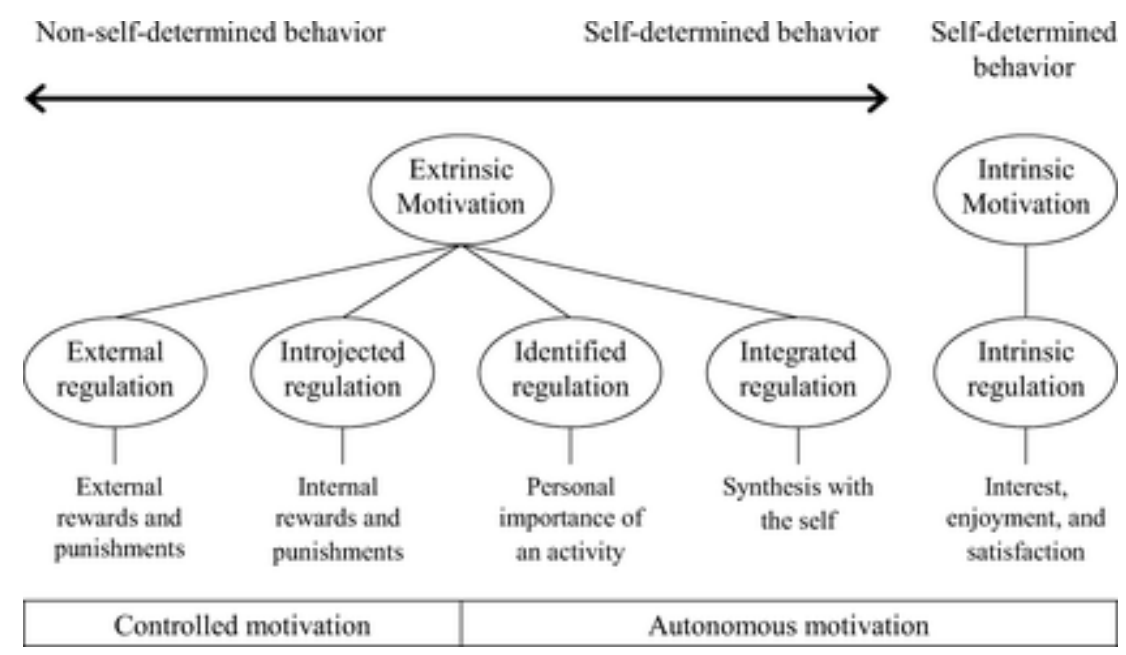

Figure 1. Ryan and Deci's Self Determination Theory Model (van Beek, Taris, Toon \& Schaufeli, 2011)

\subsubsection{Engagement}

Student engagement cannot be directly observed (Schlechty, 2002) and is "...difficult to define operationally, but we know it when we see it, and we know it when it is missing (Newmann, 1986, 242)." (McMahon, \& Zyngier, 2009). Kuh, (2009) simply states that engagement refers to the quality of effort and participation in authentic learning activities ().The challenge of student engagement has been recognised as a serious issue, especially in the middle years of schooling. Engagement, especially in the challenging middle years is now at the centre of mainstream education discussionand debate at both systemic and research levels. Vibert \& Shields (2003) define student engagement as:

A continuum, ranging from relatively rational and technical approaches to those that are more constructivist, to those reflecting a critical democratic worldview. We would suggest that not only is this a descriptive continuum, but that a move from the rational, through the interpretivist, to a more critical understanding, also approaches a more socially grounded construction of "engagement". (Vibert \& Shields, 2003, 237)

Schlechty (2002, p.64) expands this typology further:

Engagement is active. It requires the students to be attentive as well as in attendance; it requires the students to be committed to the task and find some inherent value in what he or she is being asked to do. The engaged student not only does the task assigned but also does the task with enthusiasm and diligence.

Researchers have explained different forms of engagement and teachers should be informed of these and how they work for different students under different conditions (Kuh, 2009). Newmann (1996) defined student engagement as the "...student's psychological investment in and effort directed towards learning, understanding or mastery of the knowledge" (p. 12). According to Marks (2000), engagement is closely linked with students' academic achievement and optimal human development whereas, Willms (2003) views engagement as students' feelings of belongingness to school, acceptance of school's values and active participation in school activities.

To assess student motivation researchers also have to examine engagement in and as part of learning. Blumenfeld, Kempler and Krajcik (2006) argue that motivation alone is necessary but not sufficient for academic achievement.However, Hufton, Elliott and lllushin (2002) believe that high levels of engagement show high levels of motivation. Bryson and Hand (2007) agrees with Schlechty that student engagement lies on a continuum from engaged to disengaged and that engagement is also present at a number of different degrees. Some students are interested and engage in learning activities whereas, some are bored and inactive towards the same learning task (Marks, 2000). Generally it is agreed that engagement in learning activities is important for a student's academic success. As a consequence, researchers have assessed and studied engagement by different means (Klem \& Connell, 2004). Alvarez (2002), states that if students are not engaged when doing academic tasks, then they may acquire only a very small amount of knowledge because engaged students are prepared to take a personal risk or chance in the learning task. 
Schlechty (2002) expands engagement intofive different categories which he suggests is a continuum ranging from Authentic, where astudent completes school work because the task that has clear meaning and value. Such engagement is active, it requires one to be committed to the task and find inherent value in it; Ritual, where the task has no internalvalue but has extrinsic outcomes; Passive compliance, where a task is done to avoid any negative consequences; Retreatism, where a student is disengaged from the task but does not disruptothers and does not try to substitute other activities for the assigned task and finally Rebellion,where the student refuses to do a task and may disrupt others and or substitute the learning task with other activities.

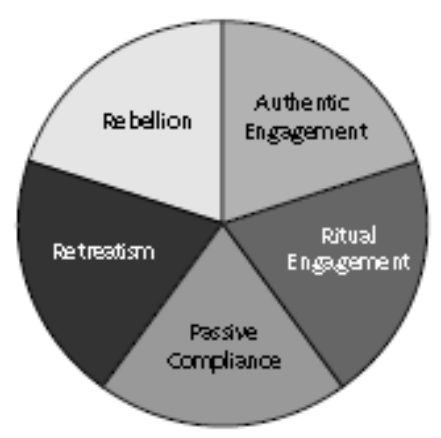

Figure 2. Schlechty's engagement framework based on student responses to school work (Schelchty, 2001)

Schlechty uses a circle (Figure 2) to indicate that engagement is a continuum and that any time a student can be variously and differently engaged as a response to the work, the context, the time of day, the teacher and peers.

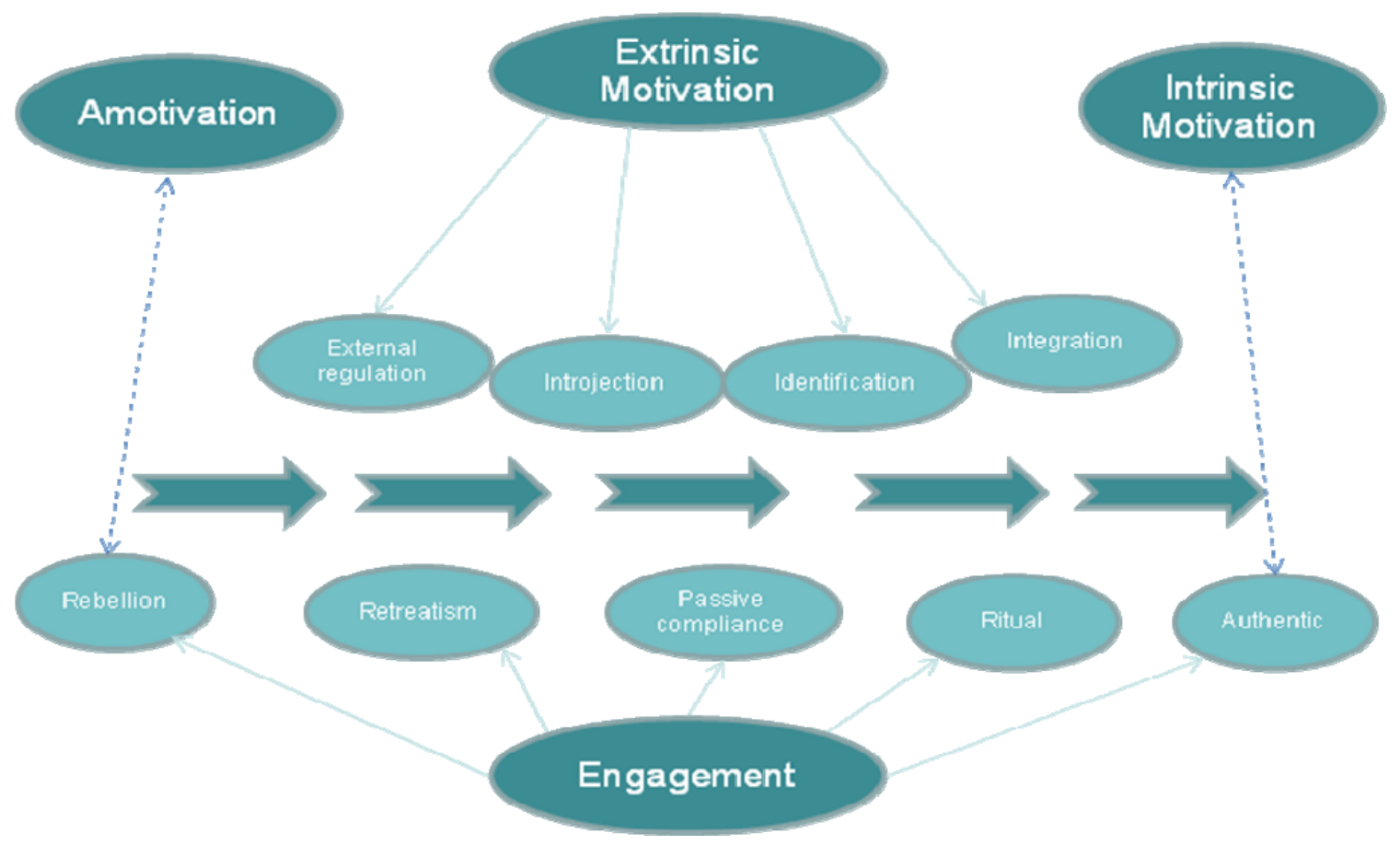

Figure 3. Linking Ryan \& Deci’ SDT framework and Schlechty’s engagement framework 
Figure 3 represents the relationship between Ryan and Deci's (2000) SDT and motivation on the one hand and Schlechty's (2002) typology for engagement on the other and the synchronicity between the two frameworks continua.

Using the Self Determination Theory (SDT) framework of motivation suggested by Ryan and Deci (2000) to understand student preferences, this paper compares and contrasts this model to the engagement typology of Schlechty (2001, 2011 attempting to understand the impact on student learning of the relationship between motivation and engagement. While these two frameworks are not equivalent, it is argued that they are largely parallel, so that a student who is a-motivated, may also be rebellious and a student who is intrinsically motivated may also be authentically engaged (Ryan \& Deci, 2000, 2009; Schlechty, 2001, 2011). Similarly, the four types of extrinsic motivation; external regulation, introjection, identification and integration are also exhibited in the ritual, passive compliance and retreatist forms of engagement. Intrinsic motivation then is very closely aligned and associated with authentic student motivation. This research will assess the efficacy and viability of this framework in relation to the current study of grade five and six students in a diverse and multicultural setting.

\section{Methodology}

Using relativist ontology and social constructivist epistemology, the researchers searched for multiple realities and meanings that were developed from the result of the interaction of the participating students within their world of school. While their knowledge is constructed and based on their engagement with other people and participants, students may give different meaning even to the same phenomenon (Crotty, 1998).

McMillan and Schumacher believe that "people's perceptions are what they consider real to them and what directs their actions, thoughts and feelings (2001, p. 396)." Therefore, the researchers explored students' thoughts and feelings in relation to their motivation and engagement. Ethical permission to participate in this research was obtained from the University, the education system, the school principal and teacher, the pupils and their parents.

\subsection{Research Participants}

As this research involves grade five and six students, a qualitative approach has been used for its well matched characteristics as it is especially suitable when the research participants are younger (Greig, Taylor \& Mackay, 2007, Holland, Renold, Ross, \& Hillman, 2010). The qualitative study gives a detailed description highlighting and centering the participants' voices (Gay, Mills \& Airasian, 2006) in the research through narrative analysis to report on the findings. By using multiple interactive methods (Creswell, 2003) including student surveys and student focus groups, detailed and triangulated information was produced, as the student focus groups asked the participants in more detail the same questions as in the surveys which served to confirm their previous written responses.

\subsection{Sampling Procedures}

Drawing on the qualitative research approach, a case study approach (Merriam, 2002) was used. Determining the participants and site for this study was one of the primary methodological decisions in selecting a classroom that contained a socially, economically, ethnically and educationally diverse range of students.

Happy Dale Primary School (a pseudonym), a suburban co-education state primary school of Melbourne was selected for the study. While originally catering for working class White Australians, the school today is culturally diverse with 36 different nationalities and 40 different languages being used by the students and their families who are migrants and refugees from Afghanistan, Cambodia, Iraq, Sri Lanka, Vietnam, the Horn of African countries such as Somalia, Ethiopia and Eretria, as well as economic migrants from near neighbors Fiji, Polynesian Islandsand Maori New Zealanders.

As this research was interested in getting the students' perceptions about intrinsic and extrinsic motivation and engagement, the aim was to get in depth information from students, one class or grade of grades five and six students $(n=24)$ between the ages of 11 to 13 was chosen as an instrumental case study or "bounded case" (Creswell, 2007, p. 74). The classroom setting was representative of the school diversity; a composite class of grade five and grade six students $(n=24)$ composed of girls $(n=11)$ and boys $(n=13)$.

\subsection{Recruitment}

Ethical approval was sought and gained from the University, the responsible education system and the school principal. Consent forms were sent home to parents as well informed assent being gained from the students and teacher involved. 


\subsection{Research Design}

The Patterns of Adaptive Learning Scales (PALS) survey (Midgley et al., 2000) was administered in a modified form to students to identify the students' perception about their own motivation type. All students were invited to participate during class time as a group in order to ensure that none feel left out or disadvantaged by not participating. This was done on the advice of the University Ethical Board. Purposive sampling was used to select participants of interest to provide information regarding the research questions (Kemper, Stringfield \& Teddlie, 2003). In purposive sampling, participants are selected on some "pre-determined criteria" (p. 58) in this case the responses to the PALS survey to ascertain their type of engagement based on Schlechty's framework (2002). On the bases of their survey responses the cases of interest of 10 studentswere purposively selected; 5 boys and 5 girls who demonstrated different types of motivation (intrinsic, extrinsic and mixed motivation type) for a semi-structured focus group conducted by the researchers. The data was recorded and transcribed for analysis. Two mixed gender focus groups were held on the same day during class time in an interview room where the students were permitted to leave the class. Over a period of 45 minutes, students were asked questions about their motivation; engagement and use of various intrinsic and extrinsic methods used by their teacher. These responses were used to examine the relationship between motivation and engagement.

\subsection{Measurement Approach}

To explore the students' motivational preferences, the PALS survey was administered to students. Students' survey responses showed that according to the SDT framework of Ryan and Deci (2000), the majority of the students in the class were intrinsically motivated or integrated regulated which is the self determined form of extrinsic motivation and is very close to intrinsic motivation. Out of 21 students in class, 11 students selfnominated as intrinsically motivated on the basis of their survey responses.

All the students both male and female showed that they were interested and enjoyed their class work and wanted to learn new skills and concepts in the class room. All the students liked group work, asked for help when needed and helped their peers in the classroom. Female students reported that they do difficult work and enjoyed it even if they made mistakes in it. Responses of female students showed that some of them have integrated regulation while some were purely intrinsically motivated. Two girls who demonstrated on the PALS survey that they were wholly intrinsically motivated wereselected. Male students' responses are indicative of having integrated regulation but none showed the tendency towards being purely intrinsically motivated. Two male students for focus group analysis whose responses were more directed towards intrinsic motivation were also included.The following section reports only on the PALS Survey responses.

\section{Results}

\subsection{Different Engagement Types Exhibited by Students' Responses}

The survey results show that only two students were extrinsically motivated in the class room. Both students were in grade five. The survey responses of both these students showed that their preferred motivation type was external regulation and introjection forms of extrinsic motivation (Ryan \& Deci, 2000) as they only wanted to get good scores in their test results with their focus on get high marks and approval from parents and teacher. They however were not interested in learning new things.

Survey responses showed that eight students indicated elements of being both intrinsically and extrinsically motivated. All the students in this group wanted to learn new skills and concepts in their class room and enjoyed doing challenging class work. Moreover, all of them showed that they asked for help when they needed it, offered support to their class mates and enjoyed doing group activities. However, they also wanted to have good marks and grades in class as compared to other students. As their survey responses are equally divided into intrinsically and extrinsically motivating items it is difficult to say that they were more inclined towards intrinsic or extrinsic motivation as a preferred way of learning. The responses of these students showed that they exhibited elements of introjection, integrated regulation and intrinsic motivation (Ryan \& Deci, 2000). Four students from this group were selected for the focus group interviews.

Students' focus group interviews were conducted to compare and contrast their survey responses, to better understand their perceptions of their motivation type and how this affected their engagement in learning. Evidence from student observation in the classroom learning environment during data collection and the student focus group responses indicate that the majority of the students were committed to and engaged in their learning. This reflects the behavioural and cognitive engagement in their survey responses. This finding is consistent with Willms (2003) who concluded that there are many students who are engaged in their studies, regularly attend their classes and many schools are very effective in promoting student engagement. However, it was observed 
that different levels of engagement as proposed by Schlechty (2002) could vary from student to student and sometimes in the responses of same student.

\subsection{Engagement in Intrinsically Motivated Students}

Students who showed intrinsic motivation and integrated regulation on their survey responses also demonstrated authentic engagement (Schlechty, 2002) in their focus group responses. Research has indicated that authentically engaged students learn more than students having ritual, passive compliance, retreatist or rebellious forms of engagement (Schlechty, 2001).

Students having intrinsic motivation, identified and integrated regulated motivation preferences in their survey response also revealed that they were authentic engaged in their focus group interviews as they liked working with their peers and participating in group work because this was beneficial for their learning.

In class we do different projects together. (Tony)

Yes because if I have trouble, I might not know it and other people know it. (Eccles)

You get to listen to other people's ideas, what they think about. (Laurel)

The majority of the students in this study revealed that they have good relations with their teacher as they viewed their teacher as "okay, nice and helping" and they reported being happy in their classroom. When asked about their relations with their teacher, students who showed intrinsic motivation, identified regulation and integrated regulation in their survey also showed what Schlechty (2002) calls authentic engagement in their focus group as they said:

Yes, because when we do work she makes it exciting for us. (Tony)

Yes, because if we're not feeling happy about the work, she tells jokes about the work and she tells us how it's really exciting and really good for us and she does things differently. (Eccles)

Teachers often use different incentives with students to achieve high academic outcomes and to promote good behavior (Pintrich \& Schunk, 2002). However, students in this groupsaid that they did not want any reward for their work but focus on their performance and on getting their work done as authentically engaged students do as explained by Schlechty (2002). They reported:

\section{I don't care. Just as long as I do it I don't mind how, if I get rewarded or not. (Tony)}

If I got a reward I would probably want books to learn more on what I was supposed to learn and maybe other learning stuff. (Carol)

However some students also showed ritual engagement in their responses:

When I get good marks I expect to be rewarded. (Eccles)

Responses of these students showed that they wanted some tangible reward for doing good work and therefore this is indicative of ritual engagement as they need something in return for their effort with the emphasis on minimums and exit requirements.

These students wanted to have even more learning activities, valued their homework and class work because it helped them to learn more. They participated in all the learning task - even the challenging and boring onesthese are all the attributes of authentic engagement as described by Schlechty (2002) and Newmann (1996) as they demonstrate commitment to their learning tasks and find inherent value in the work being prepared by their teacher. Fredricks, Blumenfeld and Paris (2004) describe behavioural engagement as students' participation in academic, social or extracurricular activities and is considered important in achieving desired learning outcomes.

Some of the students commented in relation to their work that:

You can learn new stuff. (Laurel)

Children should have a good education. (Carol)

I just want to try my best in school ... because I want to get somewhere in my life, so I want to learn what I can in school. (Tony)

Skinner and Belmont (1993) argue that engaged students are persistently involved in their learning tasks; they participate in learning activities when given chance and put extra effort and concentration in the completion of the learning task:

On the contrary, Charlotte (who on the survey indicated that she was intrinsically motivated) showed retreatism (Schlechty, 2002) in her response as she said, 
I don't think that homework is important because we do enough of it in class and I don't like work. I don't like doing work because it's boring and it makes you think .I don't like it [class work] either because it's boring.

Charlotte's response clearly shows that she was becoming disengaged from the learning tasks and did not try to put much effort into it. Schlechty (2002) named this type of engagement as retreatism as he explains that a retreatist student is disengaged from the classroom and learning activities and will only do the bare minimum to avoid punishment.

These students wanted to participate in all learning activities:

[I like] everything, all of them. Whatever activities we do ... . I just give it a go. I don't mind because I know that there's going to be something else that I will like in class. (Tony)

I still get rewarded for trying. (Eccles)

This is in line with research by Walker, Greene and Mansell (2006) that cognitively engaged students use different types of strategies and spend time to do a learning task. Similarly, Schlechty (2000) argues that in order to assess student engagement in learning it is very important to find out how much effort a student is putting in a learning task and the value and importance a student is giving to that assigned task.

\subsection{Engagement in Extrinsically Motivated Students}

The two students who showed ritual and retreatist forms of engagement (Schlechty, 2001) in their focus group interview also were found to choose extrinsic motivation in their survey responses.Both these students liked group work because of the help they received from their friends while doing a learning task and because of the games and fun they had together. Their responses might also demonstrate retreatism (Schlechty, 2002) as they did not willingly participate in learning tasks and if they did they wanted to do it in a group so that they could get help and support from other students:

Yes I like to do group work because you get a lot of help from your group. (David)

Regardingtheir relationships with their teacher the student responses showed elements of both ritual and passive compliance (Schlechty, 2002) as one of them noted;

I do sometimes [have good relationship with teacher] but I don't when I do something bad and she gets angry at me. (Andrew)

These students commented that: they wanted to have good marks and grades; looked for reward or praise on good work; left difficult and uninteresting learning tasks incomplete; wanted to have more fun and game activities; and their class/home work was only important for their future careers. As they reported:

Games, sports. For sports I just want more time and games, I just want [to have] fun. (Andrew)

I just want more time on sports and more games. (David)

Responses of both these students show a possibility of rebellious engagement (Schlechty, 2002) as these students were not interested in doing any sort of academic activities and only wanted to do sports and games. Rebellious students as described by Schlechty (2002) are disengaged from current learning activities and choose to be engaged in other contrary activities as in this case both students wanted to do only sports and fun activities instead of doing academic tasks.

These students also demonstrate elements of ritual engagement as they view class work and home work only as important in so far as a pre requisite for getting a good job or for their future study (Schlechty, 2002). According to Schlechty (2002) ritually engaged students do their learning "for reasons that are disassociated from the task itself" (p. 10). The responses of these students showed that perhaps they were doing their learning to use it for their future job and it had no intrinsic benefit for or interest to them.

Students who exhibit retreatist engagement may try to do work that may be uninteresting and if the work is difficult for them then it is left incomplete. This shows their somewhat retreatist form of engagement as they only were willing to try easy work. Research demonstrates that engaged students keep on doing the difficult and challenging learning tasks and try to achieve competence (Brownlee, 2003) while intrinsically motivated students willingly connect to their learning and put effort and focus to completing different pursuits (Brophy, 2004).

Both students were therefore likely to be retreatist as Schlechty (2002) describes retreatist students as disengaged from their learning and that they find no inherent value in their learning. Besides, they do not willingly participate in learning activities and resultantly may learn very little in class. 


\subsection{Engagement in Intrinsically and Extrinsically Motivated Students}

Students showing a combination of intrinsic and extrinsic motivation in their survey responses also revealed different types of engagement in their focus group responses ranging from authentic, to ritual, retreatist and rebellious engagement forms. These students raised the importance of their class/home work for their future job, wanted good grades and high scores on their academic tasks, left difficult and uninteresting learning activities, wanted rewards and desired praise from their teachers for good performance. Harris's response for example showed his ritual engagement as he only wanted his teacher's praise and approval on his good work as a reward:

I don't want her [teacher] to get me something; I just want her to tell me you did good schoolwork, you did good at school, and I would be happy like that. (Harris)

On the other hand some students also indicated that they may be authentically engaged and reported that they did not want any reward or praise and even wanted to do more learning activities:

I wouldn't mind [to be rewarded or not], but I like to get good marks on my work. (Lily)

The relationship that studentshave and made with their teacher shows their emotional engagement in learning (Fredricks et al., 2004). Students showing both extrinsic and intrinsic motivation in their survey showed different forms of engagement and also explained their relationships with their teacher differently. Some of these students viewed their teacher as making learning interesting and that she taught them new things every day.

Peer relations play an important role in influencing student engagement (Murray et al., 2004) and these students also indicated having good relations with their class matessaying that:

Yes. We get to hang around with them at lunchtime and we get to work together. (Lily)

Some students showing both types of motivation in their survey responses also showed authentic engagement (Schlechty, 2002) in their focus group responses. Harry felt that his class work and home work will help him in the future. He explained that it would be possible that in future:

...the work might come to you to do it, so you might do that like how you can learn from the homework to your work, how to do your work in the classroom. (Harry)

Schlechty (2011) argues that such transference is part of authentic engagement as he explained that authentically engaged students can transfer what they learn to new contexts.Some of the students also reported that they liked to participate in class room activities:

I reckon all of them [activities] are important (Harris)

Yes. I like to try all [class room activities] and what the teacher brings us, different stuff every single day .I think all of them [are important] because they are important to your life.(Lily )

However, some students also stated that they did not try to do uninteresting activities because they were hard or boring.The responses of these students showed the different types of engagement as many of their class room activities failed to engage students cognitively in their learning (Blumenfeld et al., 2006). Further, Schlechty (2002) suggests therefore that authentic academic work should be designed for students so that teacher can engage all students in the class room and that in order to authentically engage students in their learning it is important to make learning activities convincing so that students keep on doing even the more difficult tasks (Schlechty, 2001). Such activities have been described as CORE Pedagogy (Zyngier, 2007, 2008, 2011, 2012), activities that are Connected to the children's backgrounds, are Owned by the children, Respond to their needs and Empower them to see that learning and school is "for them."

\section{Discussion}

Researchers in motivation and engagement have made an important contribution to the field of education by highlighting the importance of motivation and engagement in the learning process. They also have pointed out the ways in which students' intrinsic and extrinsic motivation and engagement can influence their learning outcomes. Motivation guides learners' interest into important learning activities. It is therefore the teacher's task to design work that motivates their students "...to realize their potential by engaging them in intellectually challenging learning experiences" (Krause et al., 2006, p. 267). Teachers should know how to and are responsible for the design of such academic activities which will authentically and productively engage students in their learning. Learning that combines this authentic work has been termed pedagogic reciprocity (Zyngier, 2011), where teachers and students are learning with and from each other.

Motivation and engagement are important factors that guide behavior and as a result, it is very important for teachers to understand and use this knowledge in their teaching. By knowing how intrinsic and extrinsic 
motivations and engagement relate to students and their learning, the teacher is well placed to provide a more supportive environment for student learning and their own teaching (Marsh, 2000).

The results of this study will help teachers and teacher educators to use different strategies effectively to intrinsically and extrinsically motivate their students in order to enhance their engagement in learning to achieve the best possible student academic and social outcomes.

Engaging students is a complex process that involves more than motivating students (Wehlage, 1989). Educators need to focus on many factors to promote authentic student engagement that includes student individuality, academic tasks, the school and classroom environment and the external environment that may influence the student and school. To increase the level of student engagement requires focused teacher effort and each of the above mentioned elements should be considered and addressed.

In contrast to the findings of Arnold (2000) and Tadich, Campbell and Prain (2007), who concluded that middle years' students are often not engaged in their learning, the researchers found much evidence to support the claim that in this research study, the majority of the students were authentically engaged in their learning based on both the students' self-reporting and their teacher's observations. Accordingly to Schlechty (2002), this classroom can be termed as a highly engaged one as most of the students are authentically engaged most of the time, and all of the students are authentically engaged at least some of the time (Schlechty, 2002).This study supports and extends previous research (Bryson \& Hand, 2007; Deci, Koestner, \& Ryan, 1999; Haberman, 1991; Hufton et al., 2002; Martin, 2003; Munns \& Martin, 2005; Murray et al., 2004; Patall, Cooper \& Robinson, 2008; Reeve et al., 2004; Ryan,2000; Schlechty, 2002; Schmakel, 2008; Shernoff, Csikszentmihalyi, Schneider \& Shernoff, 2003; Smyth \& McInereny, 2007; Steele \& Fullagar, 2009; Tadich et al., 2007; Willms, 2003; Zyngier, 2007) suggesting that good teacher-student relationship; clear instructions; group work; giving choice, planning engaging and interesting learning activities; and making learning important and valuable to students all contribute to promoting and enhancing student motivation and engagement in their learning.

Our findings confirm the research that disengaged students may do their work but without interest and commitment, whereas, engaged students work hard and attempt to master their learning achieving the highest academic results they are capable of obtaining within their learning context (Appleton, Christenson, Kim \& Reschly, 2006; Fredricks et al., 2004; Furrer \& Skinner, 2003; Newmann, 1992; Skinner \& Belmont, 1993; Schlechty, 2002).

It confirms the research (Wigfield \& Eccles, 2002; Wigfield \& Waguer, 2005) that intrinsically motivated students are more competent and engaged in their learning than students who are notintrinsically motivated. It is also congruent with the research (Blumenfeld et al., 2006; Deci \& Moller, 2005; Deci \& Ryan, 2008; Deci et al., 1999) that found that when students' need for competence, relatedness and autonomy are fulfilled by their teacher (as seemed to be the case in the classroom studied), then student motivation and engagement is enhanced.

This research clearly shows that intrinsic motivation is associated with authentic studentengagement and that engaged students not only complete their learning tasks but put more effort andconcentration into the thorough understanding of the content (Newmann, 1992). Furthermore, such students are attentive, committed and enthusiastic in doing these learning tasks (Schlechty, 2002). However, in situations where intrinsic motivation is not working then teachers shouldconsider using extrinsic motivation to boost the intrinsic motivation of their students. If teachers rely only on intrinsic motivation to engage all students all of the time, they will be disappointed (Woolfolk \& Margetts, 2007). There are many situations where incentives andexternal supports may be necessary. Nevertheless, extrinsic motivation should only be used in a way that enhances intrinsic motivation rather than undermining it (Harackiewicz \& Sansone, 2000; Hidi, 2000; Lepper \& Henderlong, 2000), as extrinsic rewards have a positive effect in situations where intrinsic motivation is not high (Vialle, Lysaght \& Verenikina, 2005). Our research confirms that motivated and engaged students learn better and show best possible outcomes in their academic study and by usingthe appropriate pedagogies teachers can also make classrooms more engaging places for students to learn.

\section{Limitations}

This study like any other has certain constraints and limitations. Firstly, the methodological limitations of this study relate to scope and design. This small scale study is not intended to be representative. Through this study, the relationship between motivation and engagement of only one class was closely examined. Hence the findings may not necessarily be indicative even of other similar classrooms.

Second, in addition the power relationship of the researchers as outsiders and strangers to students may cause 
indecisiveness in expressing their views. However, in the focus group interview the students' hesitation was minimized as they were with other students and gave their opinion in a group, moreover, rapport was established with the students by visiting their class twice before data collection.

Third, the research specifically attempted to examine the students' perceptions of their motivation and engagement whereas, other factors such as, school, parents, peers and how motivation and engagement contributes to or influence the students' performance on various state standardized tests and many other factors which may play their role in student motivation and engagement were not included in the study.

\section{Future Research}

Several areas for future research arose during the study. Quantitative longitudinal research needs to be done with a larger more representative sample of students across a number of schools to more fully understand the link between students motivation and engagement, to enable the results to be generalized such data can be gathered over more than one point in time to examine any cause and effect relationship. Class room observations of students and teacher based on an established rubric can be made to closely determine students' engagement in learning and to get more detailed and accurate information on how teachers may enhance or diminish student motivation during instruction. Student motivation and engagement can also be analyzed and compared by factors such as ethnicity, class and gender to see how these differences may affected differently on students. .Lastly, other factors like parents, school, peers, social background and achievement scores could also be explored in the research to see how these factors impacton student motivation and engagement.

\section{Acknowledgements}

The authors would like to thanks the children, teacher and principal for their cooperation in this research.

\section{References}

Alvarez, D. (2002). Engaging students in their own learning. Leadership, 32(2), 12-15.

Appleton, J. J., Christenson, S., L, Kim, D., \& Reschly, A. L. (2006). Measuring cognitive and psychological engagement: Validation of the Student Engagement Instrument Journal of School Psychology, 44(5), 427-445.

Areepattamannil, S., Freeman, J., \& Klinger, D. (2011). Intrinsic motivation, extrinsic motivation, and academic achievement among Indian adolescents in Canada and India. Social Psychology of Education, 14(3), 427-439. http://dx.doi.org/10.1007/s11218-011-9155-1

Arnold, R. (2000). Middle years literature review. A report for the NSW Board of Studies part 2. Sydney.

Barratt, R. (1998). Who counts? Young adolescents: the center of attention? Paper presented at the Australian College of Education Conference. Canberra.

Bomia, L., Beluzo, L., Demeester, D., Elander, K., Johnson, M., \& Sheldon, B. (1997). The impact of teaching strategies on intrinsic motivation. Champaign, IL: ERIC Clearinghouse on Elementary and Early Childhood Education.

Blumenfeld, P. C., Kempler, T. M., \& Krajcik, J. S. (2006). Motivation and cognitive engagement in learning environments. In R. K. Sawyer (Ed.), The Cambridge handbook of learning sciences (pp. 475-488). New York: Cambridge University Press.

Bowen, E. R. (2003). Student Engagement and Its Relation to Quality Work Design: A Review of the Literature. Action Research Exchange, 2(1).

Brophy, J. (2004). Motivating students to learn (2nd ed.). Mahwah, New Jersey: Lawrence Erlbaum Associates Publishers.

Brownlee, H. (2003). Constructing youth engagement: An outline of benefits and shortcomings. Teaching Artist Journal, 1(2), 80-87. http://dx.doi.org/10.1207/S1541180XTAJ0102-03

Bryson, C., \& Hand, L. (2007). The role of engagement in inspiring teaching and learning. Innovations in Education and Teaching International, 44(4). http://dx.doi.org/10.1080/14703290701602748

Butler, R. (2012). Striving to connect: Extending an achievement goal approach to teacher motivation to include relational goals for teaching. Journal of Educational Psychology, 104(3), 726. http://dx.doi.org/10.1037/a0028613

Corpus, J. H., McClintic-Gilbert, M. S., \& Hayenga, A. O. (2009). Within-year changes in children's intrinsic and extrinsic motivational orientations: Contextual predictors and academic outcomes. Contemporary 
Educational Psychology, 34, 154-166. http://dx.doi.org/10.1016/j.cedpsych.2009.01.001

Creswell, J. (2003). Research design: Qualitative, quantitative and mixed methods approaches (2nd ed.). California, USA: Sage Publications.

Creswell, J. (2007). Qualitative inquiry and research design: Choosing among five approaches (2nd ed.). California, USA: Sage Publications.

Crotty, M. (1998). The foundations of social research: Meaning and perspective in the research process. NSW, Australia: Allen \& Unwin.

Deci, E. L., Koestner, R., \& Ryan, R. M. (1999). A meta analytic review of experiments examining the effects of extrinsic rewards on intrinsic motivation. Psychological Bulletin, 125(6), 627-668. http://dx.doi.org/10.1037/0033-2909.125.6.627

Deci, E. L., \& Moller, A. C. (2005).The concept of competence: A starting place for understanding intrinsic motivation and self determined extrinsic motivation. In A. J. Elliot \& C. S. Dweck (Eds.), Hand book of competence and motivation. New York, USA: The Guilford Press.

Deci, E. L., \& Ryan, R. M. (2008). Facilitating optimal motivation and psychological well being across life's domains. Canadian Psychology, 49(1), 14-23. http://dx.doi.org/10.1037/0708-5591.49.1.14

Fredricks, J. A., Blumenfeld, P. C., \& Paris, A. H. (2004). School engagement: Potential of the concept, state of the evidence. Review of Educational Research, 74(1), 59-109. http://dx.doi.org/10.3102/00346543074001059

Furrer, C., \& Skinner, E. (2003). Sense of relatedness as a factor in children's academic engagement and $\begin{array}{lllll}\text { performance. Journal of Educational Psychology, } & \text { 95(1), } & \text { 148-162. }\end{array}$ http://dx.doi.org/10.1037/0022-0663.95.1.148

Gay, L. R., Mills, G. E., \& Airasian, P. (2006). Educational research: Competencies for analysis and application (8th ed.). Upper Saddle River, New Jersey: Merrill Prentice Hall.

Greig , A., Taylor, J., \& MacKay, T. (2007). Doing research with children (2nd ed.). London, UK: Sage Publications.

Guay, F., Chanal, J., Ratelle, C. F., Marsh, H. W., Larose, S., \& Boivin, M. (2010). Intrinsic, identified, and controlled types of motivation for school subjects in young elementary school children. British Journal of Educational Psychology, 80(4), 711-735. http://dx.doi.org/10.1348/000709910X499084

Haberman, M. (1991). Pedagogy of poverty versus good teaching. Phi Delta Kappan, 73, 290-294.

Harackiewicz, J. M., \& Hidi, S (2000).Motivating the academically unmotivated: A critical issue for the 21 st century. Review of Educational Research, 70, 151-179.

Harackiewicz, J. M., \& Sansone, C. (2000). Rewarding competence: The importance of goals in the study of intrinsic motivation. In C. Sansone \& J. M. Harackiewicz (Eds.), Intrinsic and extrinsic motivation: The search for optimal motivation and performance. San Diego, USA: Academic Press.

Hidi, S. (2000). An interest researcher's perspective: The effects of extrinsic and intrinsic factors on motivation. In C. Sansone \& J. Harackiewicz (Eds.), Intrinsic and extrinsic motivation: The search for optimal motivation and performance. San Diego: Academic Press.

Holland, S., Renold, E., Ross, N. J., \& Hillman, A. (2010). Power, agency and participatory agendas: A critical exploration of young people's engagement in participative qualitative research. Childhood, 17(3), 360-375. http://dx.doi.org/10.1177/0907568210369310

Hufton, N. R., Elliott, J. G., \& Illushin, L. (2002). Educational motivation and engagement: Qualitative accounts from three countries. British Educational Research Journal, 28(2), 265-289. http://dx.doi.org/10.1080/01411920120122185

Kemper, A. E., Stringfield, S., \& Teddlie, C. (2003). Mixed methods sampling strategies in social science research. In A. Tashakkori \& C. Teddlie (Eds.), Handbook of mixed methods in social and behavioral research. California: Sage Publication.

Klem, A. M., \& Connell, J. P. (2004). Relationships matter: Linking teacher support to student engagement and $\begin{array}{lllll}\text { achievement. The Journal of School Health, 74(7), 262-274. } & \end{array}$ http://dx.doi.org/10.1111/j.1746-1561.2004.tb08283.x

Kohn, A. (1999). Punished by rewards: The trouble with gold stars, incentive plans, A's, praises and other bribes. 
New York, USA: Houghton Mifflin Company.

Krause, K.-L., Bochner, S., \& Duchesne, S. (2006). Educational psychology for learning and teaching (2nd ed.). VIC. Australia: Thomson.

Kuh, G. D. (2009). The National Survey of Student engagement: Conceptual and empirical foundations. New Directions for Institutional Research, 141, 5-12. http://dx.doi.org/10.1002/ir.283

Law, W, Elliot, A. J., \& Murayama, K. (2012). Perceived competence moderates the relation between performance-approach and performance-avoidance goals. Journal of Educational Psychology, 104(3), 806-819. http://dx.doi.org/10.1037/a0027179

Lee, J. Q., McInerney, D. M., Liem, G. A. D., \& Ortiga, Y. P. (2010). The relationship between future goals and achievement goal orientations: An intrinsic-extrinsic motivation perspective. Contemporary Educational Psychology, 35(4), 264-279. http://dx.doi.org/10.1016/j.cedpsych.2010.04.004

Lepper, M. R., Corpus, J. H., \& Iyengar, S. S. (2005). Intrinsic and extrinsic motivational orientations in the classroom: Age differences and academic correlates. Journal of Educational Psychology, 97(2), 184-196. http://dx.doi.org/10.1037/0022-0663.97.2.184

Lepper, M. R., \&Henderlong, C. J. (2000).Turning "play" into "work" and "work" into "play": 25 years of research on intrinsic versus extrinsic motivation. In C. Sansone \& J. Harackiewicz (Eds.), Intrinsic and extrinsic motivation: The search for optimal motivation and performance. San Diego: Academic press.

Main, K., \& Bryer, F. (2007). A framework for research into Australian middle school practice. The Australian Educational Researcher, 34(2), 91-105. http://dx.doi.org/10.1007/BF03216859

Marks, H. M. (2000). Student engagement in instructional activity: Patterns in the elementary, middle and high school years. American Educational Research Journal, 37(1), 153-184.

Marsh, C. (2000). Hand book for beginning teachers (2nd ed.). Australia: Pearson Education.

Martin, A. J. (2003). Boys and motivation. The Australian Educational Researcher, 30(3), 43-65. http://dx.doi.org/10.1007/BF03216797

McMillan, J., \& Schumacher, S. (2001). Research in education: A conceptual introduction (5th ed.). USA: Longman.

Merriam, S. B. (2002). Introduction to qualitative research. In S. B. Merriam (Ed.), Qualitative research in practice: Examples for discussion and analysis. San Francisco, USA: Jossey Bass.

Meyer, E. J. (2010). Transforming school cultures. Gender and Sexual Diversity in Schools, X, 121-139. http://dx.doi.org/10.1007/978-90-481-8559-7_7

Midgley, C., Maehr, M., Hruda, L., Anderman, E., Anderman, L., \& Freeman, K., et al. (2000). Manual for the Patterns of Adaptive Learning Scales. Ann Arbor, MI: University of Michigan.

Mitra, D. L., \& Serriere, S. C. (2012). Student Voice in Elementary School Reform Examining Youth Development in Fifth Graders.American Educational Research Journal, 49(4), 743-774. http://dx.doi.org/10.3102/0002831212443079

Munns, G., \& Martin, A. J. (2005). It's all about MeE: A motivation and engagement framework. Paper presented at the Australian Association for Research in Education Conference. Retrieved from http://www.aare.edu.au/05pap/mun05400.pdf

Murray, S., Mitchell, J., Gale, T., Edwards, J., \& Zyngier, D. (2004). Student disengagement from primary schooling: A review of research and practice. CASS Foundation, Melbourne.

Newmann, F. M. (1986). Priorities for the future: Towards a common agenda. Social Education, 50, 240-250.

Newmann, F. M. (1992). Student engagement and achievement in American secondary schools. New York, USA: Teachers College Press.

Newmann, F. M. (1996). Authentic achievement: restructuring schools for intellectual quality (1st ed.). San Francisco: Jossey-Bass Publishers.

Newmann, F., Bryk, A. S., \& Nagaoka, J. K. (2001). Authentic Intellectual Work and Standardized Tests: Conflict or Coexistence? Improving Chicago's Schools. Chicago: Consortium on Chicago School Research.

O'Brien, P., \& Lai, M. (2011). Student Voice: How can it help us to understand students' experiences of school? Assessment Symposium, Rutherford House, Wellington, New Zealand. Retrieved from 
http://hdl.handle.net/2292/16900

Patall, E. A., Cooper, H., \& Robinson, J. C. (2008). The effects of choice on intrinsic motivation and related outcomes: A meta-analysis of research findings. Psychological Bulletin, 134(2), 270-300. http://dx.doi.org/10.1037/0033-2909.134.2.270

Pintrich, P. R., \& Schunk, D. H. (2002). Motivation in education: Theory, research and applications (2nd ed.). Upper Saddle River, NJ: Merrill Prentice-Hall.

Potter, G., \& Briggs, F. (2003). Children talk about their early experiences at school. Australian Journal of Early Childhood, 28(3), 44-49.

Reeve, J., Deci, E. L., \& Ryan, R. M. (2004). Self-determination theory. In D. M. McInerney \& S. Van Etten (Eds.). Big theories revisited: Research on socio-cultural influences on motivation and learning. Greenwich, $\mathrm{CN}$ : Information Age.

Russell, V. J., Ainley, M., \& Frydenberg, E. (2005). Student motivation and engagement. Schooling Issues Digest. Australian Government, Department of Education, Science and Training.

Ryan, A. M. (2000). Peer groups as a context for the socialization of adolescents' motivation, engagement, and achievement in school. Educational Psychologist, 35(2), 101-111. http://dx.doi.org/10.1207/S15326985EP3502_4

Ryan, R. M., \& Deci, E. L. (2000). Intrinsic and extrinsic motivations: Classic definitions and new directions. Contemporary Educational Psychology, 25, 54-67. http://dx.doi.org/10.1006/ceps.1999.1020

Ryan, R. M., \& Deci, E. L. (2009). Promoting self-determined school engagement: Motivation, learning, and well-being. In K. R. Wentzel \& A. Wigfield (Eds.), Handbook on motivation at school. (pp. 171-196). New York: Routledge

Schlechty, P. C. (2001). Shaking up the schoolhouse. San Fransisco, USA: Jossey-Bass Publishers.

Schlechty, P. C. (2002). Working on the work an action plan for teachers, principals and superintendents (1st ed.). San Fransisco, USA: Jossey Bass.

Schlechty, P. (2011). Schlechty center on engagement. Retrieved from http://s3.amazonaws.com/www.schlechtycenter.org/tools/prod/4046/original/sc_pdf_engagement.pdf?12724 15798

Schmakel, P. (2008). Early adolescents' perspectives on motivation and achievement in academics. Urban Education, 43, 723-749. http://dx.doi.org/10.1177/0042085907311831

Shernoff, D. J., Csikszentmihalyi, M., Schneider, B., \& Shernoff, E. S. (2003). Student engagement in high school classrooms from the perspective of flow theory. School Psychology Quarterly, 18(2), 158-176. http://dx.doi.org/10.1521/scpq.18.2.158.21860

Skinner, E. A., \& Belmont, M. J. (1993). Motivation in the classroom: Reciprocal effects of teacher behavior and student engagement across the school year. Journal of Educational Psychology, 85(4), 571-581. http://dx.doi.org/10.1037/0022-0663.85.4.571

Smyth, J., \& McInerney, P. (2007). Teachers in the middle: Reclaiming the wasteland of the Adoloscent years of schooling. New York, USA: Peter Lang.

Steele, J. P., \& Fullagar, C. J. (2009). Facilitators and outcomes of student engagement in a college setting. The Journal of Psychology, 143(1), 5-27. http://dx.doi.org/10.3200/JRLP.143.1.5-27

Sternberg, R. J. (2005). Intelligence, competence and expertise. In E. Andrew \& D. Carol (Eds.), Hand book of competence and motivation. New York. USA: The Guilford Press.

Tadich, B., Deed, C., Campbell, C., \& Prain, V. (2007). Student engagement in the middle years: A year 8 case study. Issues in Educational Research, 17(2), 256-271. Retrieved from http://www.iier.org.au/iier17/tadich.html

vanBeek, Ilona; Taris, Toon W.; Schaufeli, and Wilmar B. (2011). Workaholic and work engaged employees: Dead ringers or worlds apart? .Journal of Occupational Health Psychology, 16(4),

Vialle, W., Lysaght, P., \& Verenikina, I. (2005). Psychology for educators. Victoria, Australia: Thomson/Social Science Press.

Walker, C. O., Greene, B. A., \& Mansell, R. A. (2006). Identification with academics, intrinsic/extrinsic 
motivation, and self-efficacy as predictors of cognitive engagement. Learning and Individual Differences 16(1), 1-12. http://dx.doi.org/10.1016/j.lindif.2005.06.004

Wehlage, G. G. (1989). Reducing the risk: schools as communities of support. London, UK: The Falmer Press.

Wigfield, A., \& Eccles, J. S. (2002). Development of achievement motivation. San Diego, USA: Academic Press.

Wigfield, A., \& Waguer, A. L. (2005). Competence, motivation and identity development during adolescence. In J. A. Elliot \& S. C. Dweck (Eds.), Handbook of competence and motivation, New York. USA: The Guilford Press.

Williams, K. C., \& Williams, C. C. (2011).Five key ingredients for improving student motivation. Research in Higher Education Journal, 12(August). $\quad$ Retrieved from http://www.aabri.comwww.aabri.com/manuscripts/11834.pdf

Willms, J. D. (2003). Student engagement at school.A sense of belonging and participation. Paris: Organisation for Economic Co-operation and Development.

Woolfolk, A., \& Margetts, K. (2007). Educational psychology. NSW, Australia: Pearson. Prentice Hall.

Zyngier, D. (2007). Listening to teachers-listening to students: substantive conversations about resistance, empowerment and engagement. Teachers and Teaching: Theory and Practice, 13(4), 327-347. http://dx.doi.org/10.1080/13540600701391903

Zyngier, D. (2008). (Re)conceptualising student engagement: Doing education not doing time. Teaching and Teacher Education, 24, 1765-1776. http://dx.doi.org/10.1016/j.tate.2007.09.004

McMahon, B., \& Zyngier, D. (2009). Student engagement: contested concepts in two continents. Research in Comparative and International Education Symposium Journals, Oxford, UK, 4(2), 164-181.

Zyngier, D. (2011). (Re)conceptualising risk: left numb and unengaged and lost in a no-man's-land or what (seems to) work for at-risk students. International Journal of Inclusive Education, 15(2), 211-231. http://dx.doi.org/10.1080/13603110902781427

Zyngier, D. (2012). Pygmalions, Galateans, and Golems: Why pre-service teacher beliefs about children from diverse backgrounds (still) matters. International Journal on School Disaffection 9 (1), 23-38. 